\title{
The Feasibility of Reforming the UN Security Council: Too Much Talk, Too Little Action?
}

\section{Seryon Lee*}

While a broad consensus exists over the necessity of reforming the Security Council, the disagreement among the different groups of member States prevails in great part due to the enlargement and category of membership and the working methods. Such divergence in views attributed to the stalemate in the debate over the Security Council's reform. However, the recent discussion has gained momentum since the launch of the intergovernmental negotiation at the UN level. The key issues surrounding the UN Security Reform include the size of an enlarged Council, categories of membership with proper regional representation, the veto, working methods and relations with the General Assembly. It is essential not only to properly assess the content of the different proposals to bring out the most 'sensible' solution, but the attitude of the five permanent members should also be closely examined. In any case, the potential changes in the structure of the Security Council would ultimately require a unanimous decision of the 5 P States. This article aims to review the historical development of the Security Council's reform debate and concentrate on the most contentious questions by analyzing the content of the relevant proposals to test the feasibility of each option.

\section{Keywords}

UN Security Council Reform, G4 Proposal, UFC Proposal, Ezulwini Consensus

* Professor of International Law at Chonbuk National University( “CNU”) School of Law, Korea, B.A.(Chicago), LL.B.(CNU), LL.M.(NYU), Ph.D.(Yonsei). The author may be contacted at: seryon@jbnu.ac.kr / Address: 567 Baekjedaero, Deokjin-gu, Jeonju-si, Jeollabuk-do, 561-756 Korea. 


\section{Introduction}

It is incontestable that the United Nations Security Council ("UNSC") remains as an important ground of legitimacy for international peace and security. This legitimacy is defined as "the belief by states that the [Security] Council has the right to make authoritative decision in its area of legal competence." 1 While the legitimacy of the Security Council is closely related to the effectiveness of its mandate, 2 the major criticism faced by the Security Council is not so much about its lack of efficiency alone. The legitimacy of the Security Council has been constantly under attack for obsolescence particularly in terms of its underrepresented geopolitical structure and decision-making procedures as well as for what seems to be an indefinite stalemate on the issue of reform. ${ }^{3}$ The proposed structural changes in the Security Council include, but are not limited to, membership composition, category of membership, proper geographical representation, voting power and more transparent working methods. ${ }^{4}$ In the course of debate over the Security Council's reform, the UN member States often face a dilemma of maintaining a balance between representation, legitimacy and efficiency. ${ }^{5}$ For instance, an increase in the membership of the Security Council would make it more representative, yet a broad expansion might, at the same time, inevitably limit its

1 Ian Hurd, Myths of Membership: The Politics of Legitimation in UN Security Council Reform, 14 GLOBAL Governance 201-202 (2008). In this article, Hurd further explains that this 'right' is a normative one that those state with such belief would be inclined to feel "a normative obligation to respect the decisions of the Council." Moreover, this belief, according to Hurd, produces significant effects when it is shared by many States.

2 For instance, Hurd offers a casual connection between legitimacy and the Council reform in four linked steps. In the first step, inequality led to loss of legitimacy. In the second step, loss of legitimacy means loss of effectiveness. At this moment, changes in structure would, according to Hurd, increase in legitimacy, thereby subsequently increasing effectiveness. Id. at 202-203.

3 Kara C. McDonald \& Stewart M. Patrick, UN Security Council Enlargement and U.S. Interest, 59 Council on Foreign Relations Special Report 7 (Dec. 2010). However, the legitimacy of the Security Council from the perspective of current permanent members seems to be clear on the present geographic representation because equitable regional representation was not the basis for designating the permanent members; rather, the ability to perform a role as a guardian of international peace was a principle criterion. Besides there existed a room to keep the regional balance in the elected seats for non-permanent members with the explicit provision in Article 23 of the UN Charter, mentioning "equitable geographic distribution."

4 Thomas G Weiss, The Illusion of UN Security Council Reform, 26 The Washington Quarterly 148 (2003). Professor Weiss comments that the term 'reform' used by UN staff members referred to the routine measures involving personnel changes and management, but now the term applies in a much more broader scope to encompass the constitutional changes in the UN Policy.

5 Dimitris Bourantonis, The History and Politics of UN Security Council Reform 10 (2005). Bourantonis explains that this concept of 'reform' of the Security Council is distinguished, depending on the way the reform is effected, between 'de jure' and 'de facto' reform with the former referring to changes through amendments in the text of the UN Charter and the latter referring to changes without formal amendments of the Charter. 
effectiveness as a political organ. ${ }^{6}$ While there is general agreement as to the need for the Security Council to reflect the dramatic shift in the international political environment since its inception in 1945, the previous efforts on this issue have proven fruitless. ${ }^{7}$ It is quite understandable that the past efforts for reform, often driven by political will, met with little success, because a diversity of membership results in a divergence of member States' interests, 8 let alone the difficulty of amending the procedure of the UN Charter. ${ }^{9}$

Demands for reform of the Security Council had been on the General Assembly's agenda as far as back in 1979 having attracted little interest.10 The issue of the Council reform became feasible as a virtually global consensus was reached on the need for a thorough review of its structure.11 The reform issue was eventually included in the deliberations of the General Assembly with the establishment of the "Open-Ended Working Group ("OEWG")." Reform stalled until the General Assembly decided to move the discussions of the Security Council reform to the level of the Intergovernmental Negotiations in 2008.12 Subsequent to this decision, a work plan was presented with the five distinguished key issues including categories of membership, the veto, regional representation, size of an enlarged membership, and working methods of the Security Council. The member States' views are sharply divided particularly over the categories and enlargement of membership.

The primary purpose of this article is to assess the UNSC reforms and find ways to overcome the challenges surrounding reform. Part two will briefly review the development on the reform issues of the Security Council. Part three will examine major proposals by different group of the member states. Part four will discuss the key issues surrounding the reforms. A final observation will include the assessment of obstacles to

6 Id. at 10.

7 The very first amendment was made in the expansion of seats for non-permanent members in 1963 . Article 109 of the UN Charter was amended to modify the majority required in the Security Council in 1968. In 1973, the Economic and Social Council was expanded from 27 to 54 members.

8 As the Republic of South Sudan formally seceded from Sudan, it became the 193 ${ }^{\text {rd }}$ member State of the UN on July 14, 2011.

9 Article 108 of the UN Charter provides that: "Amendments ...shall come into force for all members of the United Nations when they have been adopted by a vote of two-thirds of the members of the General Assembly and ratified in accordance with their respective constitutional processes by two-thirds of the members of the United Nations, including all the permanent members of the Security Council."

10 Supra note 5 , at 33.

11 G.A. Res. 48/26 (Dec. 3, 1993). This resolution, which reads in relevant part that “...recognizing the need to review the membership of the Security Council and related matters in view of the substantial increase in the membership of the United Nations, and bearing in mind the need to continue to enhance the efficiency of the Security Council... [and being] mindful of the importance of reaching general agreement..." [Emphasis added] decides to establish an Open-ended Working Group to consider the question of increase in the membership of the Security Council.

12 Elisabetta Martini, UN Security Council Reform: Current Developments, Instituto Affari Internazionali ( "IAI")0926, available at http://www.iai.it/pdf/DocIAI/iai0926.pdf (last visited on Oct. 1, 2011). 
the feasibility of the proposed reforms.

\section{Evolution of the Reform Debate}

The early years of the UN passed without any significant complaints except for the attempts made with respect to change voting arrangements at the initiative by Argentina and Cuba in the 1950s.13 While the issue of enlargement of the Security Council was raised in 1955 for an increase of the non-permanent seats by sixteen newly admitted Latin American States, the rigid attitude of the Soviet Union proved to be the biggest challenge in the expansion of the Security Council.14 By 1963, the large influx of newly admitted States consequently increased the level of competition for nonpermanent seats in the Security Council as such a dramatic increase in membership led to the 'uncomfortable' ratio of the total number of UN members to the number of seats in the Security Council.15

The discussion on an increase in the membership in the Security Council and the Economic and Social Council had begun in 1959 at the 14th session of the General Assembly 16 and eventually culminated in the adoption of a breakthrough resolution in 1963.17 The adopted resolution, at last, increased the number of non-permanent seats in the Security Council by four non-permanent members. A distinctive feature of this resolution was that for the first time a clear and agreed pattern of distribution of the non-permanent seats among four different 'regions,' rather than the term 'group,' was officially promulgated. 18 Marking as the first and the latest amendment in the history of the UN, the 1963 amendment brought more than two-thirds of the member States, including all the UNSC permanent members, to deposit their instruments of ratification by the end of August 1965.19 Since 1965, the membership of the UN had continued to

13 Natalino Ronzitti, The Reform of the UN Security Council, IAI Document 10|13, 7 (July, 2010), available at $\mathrm{http}: / /$ www.iai.it/pdf/DocIAI/iai1013.pdf (last visited on Oct. 1, 2011).

14 Supra note 5, at 17-18. The Soviet Union firmly insisted that there will be no positive solution to the issue of Council enlargement unless the People's Republic of China was fully represented in the UN.

15 Id. at 14. Between 1955 and 1960, the UN membership had risen from 51 to 99 . By end of 1963, the membership rose to 113 with dramatic changes in the number of African and Asian members constituting more than half of the UN membership.

16 G.A. Res. 1404 (XIV), U.N. Doc. A/4256 (Nov. 25, 1959).

17 G.A. Res. 1991(XVIII) (A), U.N. Doc. A/5675 (Dec. 17, 1963).

18 Supra note 5, at 27. According to the Resolution, 10 non-permanent members were to be elected 5 from Africa and Asia, 2 from Latin America, 2 from Western Europe, one from Eastern Europe.

19 Supra note 3, App. 2. It must be noted that the 1965 expansion was conducted in the wake of decolonization, which, in turn, gave birth a large number of new, non-aligned states. Unlike contemporary debate, the 1960s debate did not 
increase mainly due to the emergence of the newly independent States from Asia and the Pacific, Africa and Lain America, thereby reigniting the discussion for increasing membership of the Security Council. The attitude of the five permanent members might be attributed for a somewhat successful debate during this period as they also recognized the urgent need to correct the imbalances of representation in the Security Council. More significantly, any discussions to affect their privileged positions were left intact.

In the 1980s, however, the demand for reform remained at a standstill due to the ongoing tensions of the Cold War. Reform reemerged in 1992 when, for the first time, the Security Council convened on the Heads-of-State-level and mandated the then Secretary-General to draft a comprehensive reform of the structures of the UN.20 In line with this movement, the General Assembly established an Open-Ended Working Group to exclusively deal with reforming the Security Council.21 In 1997, Razali Ismael, chairman of the OEWG, submitted a draft resolution of the General Assembly, known as "Razali Reform Paper," proposing an ambitious plan to add five new permanent members and four new non-permanent members of the Security Council.22 The reaction of the five permanent members to the Razali plan varied; while most western powers reacted rather reservedly, the United States generally welcomed the idea and expressed a promise for its continued support. 23 More recently, in 2010, the General Assembly, mandated by its previous resolutions and decisions, 24 decided to immediately continue intergovernmental negotiations on Security Council reform in its informal plenary session. 25

22 U.N. Doc. A/AC.247/1997/crp.1, A/51/47 Annex II. The Razali paper proposed five permanent members to be elected according to the following representation: one from Africa, one from Asia, one from Latin America, and two from industrialized states. Germany and Japan were two industrialized states that Razali had in mind as possible candidates for new permanent members. Also, the new four non-permanent members were to represented from Africa, Asia, Eastern Europe and Latin America.

23 Supra note 5 , at 76.

24 G.A. Decision 62/557 (Sept. 15, 2008); G.A. Decision 63/565 (Sept. 14, 2009).

25 G.A. Decision 64/568 (Sept. 13, 2010). As of March 3, 2010, there had been four rounds of negotiations since the process of discussions shifted from the Open-ended Working Group in 1993 to intergovernmental negotiations. The UN Press Conference available at http://www.un.org/News/briefings/docs/2010/100303_SC_Reform.doc.htm (last visited on Oct. 1, 2011). 


\section{The Major Proposals for Reform}

\section{A. High-Level Panel Report and Kofi Annan's Proposals}

In search for a possible solution to the deadlock over reform, two major documents were presented on the occasion of the UN World Summit in 2005: the first document was the final report of the High-Level Panel Talk;26 the second document was the Secretary-General's report entitled, "In Larger Freedom: Towards Development, Security and Human Rights for All.” 27 These reports subsequently produced two different versions of proposals known as Model A and Model B. The first model proposed expanding the total number of Security Council seats to 24, including three non-permanent seats and six new permanent seats without veto power. The second model also expanded the number of Security Council seats to 24, but did not include new permanent seats; rather it created eight seats with four-year renewable terms. In each model, a certain number of seats were allocated on a regional basis. However, due to the huge population disparity, the regional groupings could raise doubts whether the UN's democratic principles would be properly upheld.28

\section{B. The Group of Four Proposal}

In July 2005, the Group of Four ("G4"), composed of Brazil, Germany, India and Japan, put themselves forth as the main candidates for the permanent seats in the Security Council by submitting a draft resolution on a proposed expansion of the UN Security Council for an early vote in the General Assembly. However, the so-called 'G4 proposal' did not succeed in 2005 because it did not achieve the required two-thirds majority support in the General Assembly. As each of the four countries wield growing economic and political clout in world and regional affairs, it is understandable that they should seek to raise their international status and assume greater international

U.N. Doc. A/59/565 (Dec. 2, 2004), The Report of the Secretary-General, High-Level Panel on Threats, Challenges and Change, A More Secure World: Our Shared Responsibility, available at http://www.un.org/secureworld/report.pdf (last visited on Oct. 1, 2011).

27 U.N. Doc. A/59/2005 (Mar. 21, 2005), U.N. GAOR, 59th Sess. The Report of the Secretary-General, available at http://www2.ohchr.org/english/bodies/hrcouncil/docs/gaA.59.2005_En.pdf (last visited on Oct. 1, 2011).

28 Center for UN Reform Education, The United Nations Security Council: Reforms concerning its membership-An Overview, available at http://www.centerforunreform.org/system/files/Overview+(2007).pdf (last visited on Oct. 1, 2011). The Americas, Europe and Africa have roughly similar populations ranging between 727 million and 857 million. On the other hand, the Asia Pacific group accounts for a population of approximately 3 billion 836 million people. 
responsibilities. Yet, some differences persist even inside the G4; while India and Brazil firmly pursue a strategy based on a bold position, Germany is engaged in striking a balance between national aspirations and European commitments. As a result, Germany has demonstrated openness to intermediary agreements as long as these agreements have a good chance of gaining the necessary two-thirds majority support in the General Assembly and are backed by the other two major European powers, namely France and the UK. Brazil and India insist on emphasizing the problems with the intermediate reform even in terminological terms. Accordingly, intermediate reform would be nothing more than a variation of the concept of non-permanency. ${ }^{29}$ On February 12, 2011, the G4 countries renewed their calls for an enlarged Council by issuing a joint statement to press for tangible results in enlarging the Security Council.30 The G4 alleged in their joint statement that their proposal for enlarging the Council was widely supported by UN member nations, but did not indicate how many or which countries supported their position. Hence, it is still premature to claim a broad acceptance among the 193 UN member States on how to reform the world's supreme peace and security body.

A close look at the G4 proposals reveals overall shortcomings as well as individual weaknesses for each aspiring country. The common issue among the G4 States is the strong resistance from neighboring countries such as Pakistan, Korea, Italy and Argentina. Moreover, each individual State has to overcome its own weaknesses. Despite the strong economic power and high level of contribution to UN's budget, Japan lacks the moral grounds to be considered seriously. Japan must first repair its 'unraveled' ties particularly with the Republic of Korea and China for atrocities committed during World War II if Japan desires to play a greater political role in the UN. ${ }^{31}$ For instance, while China is generally aware of the need to reflect the changing

29 Supra note 12.

30 The Minister of the G4 countries met in New York on September 23, 2011, on the occasion of the 66 th session of the United Nations General Assembly to exchange views on Security Council reform. Recalling their previous joint statements, in particular the declarations of September 2010 and February 2011, the G4 countries reiterated their common vision of an enlarged Security Council in both the permanent and non-permanent categories of membership as well as the need for increased representation of developing countries in both categories.

31 Philip P. Pan, Japan-China Talks Fail to Ease Tensions, The Washington Post, Apr. 18, 2005 available at http://www.washingtonpost.com/wp-dyn/articles/A60258-2005Apr17.html (last visited on Oct. 1, 2011). In 2005, a series of anti-Japanese protests erupted across the East Asian region in the wake of Japan's approval of a new history textbook, which was perceived as expunging its past atrocities as well as Japan's proposal for the permanent seat in the UN Security Council. China indicated that it would not back a seat for Japan unless Japan fully apologies for its invasion of China in the first half of the last country. As far as Korea is concerned, while Japan at least acknowledged its colonial rule over Korea as "a tragic incident" at the ministerial meeting held on on February 11, 2011, this statement received a mixed reaction of support and dissatisfaction. See Japan Apologizes for Colonial Rule of Korea, CNN WoRLD, Feb. 11, 2011, available at http://articles.cnn.com/2010-02-11/world/japan.korea.apology_1_korea-andchina-comfort-women-south-korea?_s=PM:WORLD. (last visited on Oct. 1, 2011). 
international political scene in the membership of the Security Council, Jiang Zemin once claimed that "the wealth of a country should not be the sole condition taken into consideration, and that the principle of fair regional distribution, and the principle of unanimity in consultation should be fully honored" in approaching the issue of expanding permanent seats in the Security Council.32 A major challenge for Germany is that its addition would overly enlarge Europe's representation in the Security Council's permanent members. India and Brazil's limited contributions to the UN budget would be a barrier for their candidacy as permanent members. 33

\section{The Uniting for Consensus Proposal}

Opposing the G4 Proposal, the Uniting for Consensus ("UFC") was formed with a group of approximately 40 States under the leadership of Italy, Pakistan, the Republic of Korea and Colombia. The reasons underlying this opposition are considered as quite reasonable since each of these States strongly counter against so-called "unjust reduction of their international political relevance." 34 After having agreed with the need to increase the representativeness of the Council, the proposal focused on an enlargement of the number of non-permanent members from 10 to 20 in 2005 by the terms of the text by the 12-strong group of member States. 35

On April 20, 2009, Columbia and Italy, as representatives of UFC Group presented a new model of reform, which included creation of a new category of seats with nonpermanency for an extended duration, possible from three to five years without the possibility of immediate reelections. ${ }^{36}$ These new types of seats would not be allocated to individual countries, but rather to regional groups on a rotational basis. The most recent proposal by the UFC on the issue of Security Council reform is found in the agenda item 119 in the 64th Session of the General Assembly in 2010.37 This document, which was presented by the delegations of Columbia and Italy during the intergovernmental negotiations, called for the establishment of "a more democratic, equitably representative, transparent, effective and accountable Council" with a particular attention to the substantial increase in the membership of the Council.38 In short, the UFC proposal

38

Jian Yang, SinoJapanese Relation: Implication for Southeast Asia, 25 CONTEMPORARY SOUTHEAST AsIA 308-309 (2003).

Supra note 3, at $42-43$.

Supra note 12 , at 2.

UN Press Release, United Nations General Assembly, "Uniting for Consensus" Group of States Introduces Text on Security Council Reform to General Assembly, U.N. Doc. GA/10371 (July 26, 2005).

Supra note 12 , at 2 .

U.N. Doc. A/64/CRP.1 (Jan. 21, 2010), available at http://www.italyun.esteri.it/NR/rdonlyres/3661BCE2-6BFC-49A281E8-F8FFBFB58FE8/0/20100210125245277.pdf (last visited Oct. 1, 2011).

Id. This proposal suggests the comprehensive reforms of the Security Council including not only an increase in the 
requires long-term seats for regional groups on a rotational basis.

\section{The Ezulwini Consensus by the African Union}

The African Union ("AU") adopted, pursuant to the aforementioned High-Level Panel report, a Common African Position on the proposed reform of the UN, known as "The Ezulwini Consensus." 39 On the reform of the Security Council, the AU called for full representation of Africa, specifically meaning "not less than two permanent seats with all the prerogatives and privileges of permanent membership including the right of veto." 40 The AU further proposed that the selection of Africa's representatives in the Security Council and the questions of the criteria for such selection should be reserved for the AU. South Africa and Nigeria have been outspoken about their representative role to possibly secure the seat for the two permanent seats, yet they are confronted with a number of weakness such as limited military and diplomatic power.

\section{Key Issues surrounding the Reform}

In 2007, the President of the General Assembly, Sheikha Al Khalifa, identified the following five key issues: 41 the size of an enlarged Security Council, the categories of membership, regional representations, extending veto power to additional member States, and the working methods of the Security Council and its relationship with the General Assembly.42 While these areas overlap to a great extent, the size and category of membership are the most contentious issues particularly between the G4 and the UFC. For obvious reasons, the Small-Five Group ("S5"), consisting of Costa Rica, Jordan, Liechtenstein, Singapore and Switzerland have not shown interest in the Council enlargement, rather they seem to attach more importance to reform that will bring about a more transparent, accountable and accessible Security Council.43 In the following

size of the membership, but an improvement in overall working methods. As far as additional seats are concerned, the allocation of seats are divided into longer-term, and regular non-permanent seats.

39 Ext/EX.CL/2(VII), African Union Executive Council, $7^{\text {th }}$ Extraordinary Session (Mar. 7-8, 2005).

40 Ext/EX.CL/2(VII), African Union Executive Council, at 9.

41 On February 9, 2007, the President of the GA convened the first informal meeting of the OEWG on the Question of Equitable Representation on and Increase in the Membership of the Security Council, available at http://www.un.org/apps/news/story.asp?NewsID=21506\&Cr=general\&Cr1=assembly (last visited on Oct. 1, 2011).

42 Jacob Silas Lund, Pros and Cons of Security Council Reform, Center for UN Reform Education (Jan. 19, 2010), available at http://www.centerforunreform.org/node/414 (last visited on Oct. 1, 2011).

43 On April 14, 2011, the Small Five Group, consisting of Costa Rica, Jordan, Liechtenstein, Singapore and 
section selected issues of membership and working methods will be discussed.

\section{A. Membership: Size and Category}

The case for expansion of the UN Security Council along with the categories of membership is the most contentious issue. The discussion on the expansion is often related to an overall representation of the UN membership.44 This relation has prompted more debate over the 'proper' size and geographic parity of an enlarged Council, rather than its effectiveness in performing its mandate. It is likely that the enlargement would definitely hinder efficiency of the Council, yet this impact of effectiveness is difficult to predict because it depends on how many members are added, what form the membership takes, and most importantly, which countries are selected. 45

Most proposals discussed so far regarding the size of a reformed Council fall between the low to mid-20s.46 In short, those who favor expansion cite a lack of democracy and insufficient geographic representations as the most compelling reasons for reform, whereas those having reservations with expansion are concerned with the negative impact expansion would have on the effectiveness of the Security Council.47 In light of such tension, non-expansion of membership, as argued by Lund, would be a viable option. 48 Lund further notes that the permanent members of the Security Council might express their disfavor for reform under the guise of intentionally supporting a particular candidate, knowing that such support will be blocked by an opposing candidate. 49

As far as the category of membership is concerned, the debate on this particular issue is distinguished between the expansion of both permanent and non-permanent positions versus the extension for non-permanent seats only. 50 For both permanent and non-permanent categories, the African group proposes two permanent and five non-

Switzerland, presented a draft resolution for Improving the Working Methods of the Security Council. The resolution was presented under agenda item 115 of the General Assembly that deals with follow-up to the outcome of the Millennium Summit.

44 Supra note 3 , at 17.

45 Id. at $17-18$.

46 Supra note 42. A higher twenties option was rarely advocated, yet this option would allow a wider and better geographical representation.

47 Id.

48 Id.

49 Supra note 13, at 10. For instance, France and the UK, which have often expressed support for the G4 proposal, suggested the option of an intermediate reform in July 2009. This option includes the creation of a new temporary category of seats with longer terms than the current two-year term, yet this 'intermediate reform' was met with harsh criticism as a possible guise of status quo option. See also supra note 12.

50 Id. at $11-12$. 
permanent seats to African States, while the G4 countries hope for six permanent and four non-permanent seats. 51 Expansion only in the non-permanent category is strongly supported by the UFC countries, with long-terms seats allocated to the regional group on a rotating basis and a two-year term without possibility of immediate reelection for small States (population below one million), medium-size States (population between one and 10 million). The Korean proposal is similar to that of the UFC proposal, however, it requires the possibility of creating a new category of seats with a longer mandate of 8 to 10 years with the possibility of reelection. 52

The question arises as to the criteria that should be allowed for determining permanent membership. Permanent membership in the Security Council confers both rights and responsibilities, yet most of the time, much focus is given to the privileges such as possible veto over certain actions by the Security Council, and the 'unwritten' privileges, commonly known as the "cascade effect of permanent membership," 53 to secure seats on other major UN organs. Consequently, less attention is given to the obligation inherent in permanent membership. 54 This idea of power representation is derived from the realist theory that the UN could work effectively only when the most powerful members are conferred with sufficient authority and competence. 55 The common grounds would include a history of political stability, globally deployable military capabilities, and financial contributions to the UN's regular budget. It is virtually impossible to identify any State that meets all these criteria, and even some current permanent members would have difficulties in fulfilling them all. This criteriabased approach usefully shifts the focus of conversation from entitlement to qualifications and steers negotiations away from framework proposals that leave the selection of permanent members to regional groups.

Along with a reasonable criteria-based approach, the current attitudes of the permanent members should also be properly assessed. France is, by far, the most enthusiastic about enlargement. France officially supports the accession of Germany, Brazil, India and Japan to permanent member status and also endorses an increased presence of African countries within the Security Council, in particular, among its permanent members. 56 From 2008-2010, France and Britain jointly proposed to create an

51 Id.

52 Id. at 11-12.

53 This cascade effect often includes a de facto right to have permanently a judge at the International Court of Justice, and the right to be permanently present at the General Committee of the General Assembly. For further information on the cascade effect of permanent membership, see U.N. Doc. A/AC.247/5(a) (Sept. 14, 1995).

54 Supra note 3 , at 21.

55 Supra note 5 , at 6.

56 See the official website for Permanent Mission of France to the UN, available at http://www.franceonu.org/ spip.php?article3767 (last visited on Oct. 1, 2011). 
interim category of longer-term, renewable seats for five to 15 years. 57 While Russia anticipates keeping permanent membership as compact as possible, 58 China is at least open to the option of expansion to include additional elected members. 59 The U.S policy on the Security Council reform can be inferred by the statements in support of a limited expansion of both permanent and non-permanent members. 60 The Obama administration's stance no longer conditions movement on the expansion to the UN budgetary reform. Contrary to the Bush administration which supported only Japan's candidacy, the current administration has announced support for India as additional permanent members. 61 On the whole, the United States has chosen to focus on an organization-wide reform of the UN rather than focusing primarily on the Security Council. The focus on overall problems of the UN represents the desire to increase the effectiveness of the organization, but also illustrates U.S. hesitance in completely restructuring the Council.62

\section{B. Working Methods}

The points for a broad reform of the Security Council's working methods were spelled out in the so-called '507 note.' 63 In wake of the 507 note, the S5 stressed the importance of improving the working methods of the Security Council in March 2010. More recently on August 1, 2011, the permanent representative of Finland, Ambassador Jarmo Viinanen, submitted the report of the relevant workshop to the General Assembly, which includes the following discussions: 64

Id. On January 30, 2011 the Speech delivered by Mr. Nicolas Sarkozy, President of France at the African Union Summit, includes the statement that: "We[France] have been talking about the reform for 30 years now. I propose that we do it this year, in 2011. The elements are on the table. We know that we need to increase the number of Security Council members, no doubt with an interim reform phase."

58 Position of the Russian Federation at the 65th Session of the General Assembly; Website of Permanent Mission of Russia to the UN available at http://www.un.int/russia/new/MainRoot/index_plain.html (last visited on Oct. 1, 2011).

59 Remarks by Ambassador Wang Guangya at the meeting on "Uniting for Consensus," supporting the initiatives of UFC proposal on April 11, 2005; Website of Permanent Mission of the People's Republic of China to the UN, available at http://www.china-un.org/eng/zt/gaige/t191026.htm (last visited on Oct. 1, 2011).

60 Supra note 3 , at 13.

61 BBC News on November 8, 2010, Obama backs India on permanent UN Security Council Seat, available at http://www.bbc.co.uk/news/world-south-asia-11711007 (last visited on Oct. 1, 2011).

62 Supra note 3, at 16-18.

63 See Note by the President of the Security Council, U.N. Doc. S/2006/507, available at http://www.un.org/en/sc/ repertoire/Notes/s-2006-507.pdf (last visited on Oct. 1, 2011).

64 See Security Council Working Methods-A Work in Progress?: Security Council Report 1 (Mar. 30, 2010), available at http://www.securitycouncilreport.org/site/c.glKWLeMTIsG/b.5906427/k.91B7/Special_Research_Report_No_1brSecu rity_Council_Working_MethodsA_Work_in_Progressbr30_March_2010.htm (last visited on Oct. 1, 2011). 
- extending the veto to new, semi-permanent members;

- abolishing the veto for genocide and other crimes against humanity;

- extending the veto to semi-permanent members conditionally; and

- completely abolishing the veto.

To date, three different visions with respect to reforming the Security Council working methods are available. The first is the "thematic reform approach" under which the Council would adopt one of a series of sweeping decisions to formally rearrange its working process. The second is the "incremental case-specific approach" under which the Council would be open to evolution driven principally by the needs of specific situations. The third approach, also known as "do not fix what is not broken" tactic, is applied in circumstances where provisional rules of procedure and historical practice should be strictly applied in order to prevent the Council members from being burdened with an overwhelming workload. 65

\section{Conclusion}

This article has examined the long history of debate over the reform of the Security Council, and identified major proposals by different groups to assess the feasibility of each group's contention. The key issues surrounding reform of the Security Council are summarized as to include the suitable size for an enlarged Council, categories of membership with proper regional representation, allocation of the right to veto to potential permanent members, more transparent and accessible working methods and relations with the General Assembly.

Some conclusions seem to emerge particularly from the foregoing section on proposed reforms. The highest obstacle to the proposed reform is obviously the political-oriented nature of the reform itself. Moreover, additional problems lie in the reforms involving amendments to the UN Charter, which would be very difficult to achieve. The debate over reform of the Security Council has been ongoing without providing a certain outcome. Due to significant differences on various issues among member States, the process of reform had sometimes been deadlocked for years. Reform is a long-term process which requires prudence and commitments by all the member States, and particularly genuine efforts and collective responsibility of the five permanent members. The fact that numerous proposals have not yet resulted in 


\section{Seryon Lee}

significant changes highlights the complexity of the process. Yet, recent developments, including somewhat 'open' attitudes by the five permanent states, have given rise to modest optimism. As former Secretary-General Kofi Anan emphasized, "no reform of the UN will be complete without the reform of the Security Council." 66

66 U.N. Secretary General, Need for Security Council Reform Never Greater; Until Then, un Handicapped by Perception of Inequitable Share of Power, U.N. Doc. SG/SM/10650 (Sept. 21, 2006), available at http://www.un.org/ News/Press/docs/2006/sgsm10650.doc.htm (last visited on Oct. 1, 2011). 